\title{
The response of calcifying plankton to climate change in the Pliocene
}

\author{
C. V. Davis ${ }^{1, *}$, M. P. S. Badger ${ }^{1,2}$, P. R. Bown ${ }^{3}$, and D. N. Schmidt ${ }^{1}$ \\ ${ }^{1}$ Organic Geochemistry Unit, Bristol Biogeochemistry Centre and The Cabot Institute, School of Chemistry, University of \\ Bristol, Cantock's Close, Bristol, BS8 1TS, UK \\ ${ }^{2}$ Organic Geochemistry Unit, Cabot Institute and Bristol Biogeochemistry Research Centre, School of Chemistry, University \\ of Bristol, Cantock's Close, Bristol, BS8 1TS, UK \\ ${ }^{3}$ Department of Earth Sciences, University College London, London WC1E 6BT, UK \\ *now at: Bodega Marine Laboratory, University of California Davis, Bodega Bay, CA 94923, USA
}

Correspondence to: M. P. S. Badger (marcus.badger@bristol.ac.uk)

Received: 28 March 2013 - Published in Biogeosciences Discuss.: 17 April 2013

Revised: 19 August 2013 - Accepted: 25 August 2013 - Published: 30 September 2013

\begin{abstract}
As a result of anthropogenic $p \mathrm{CO}_{2}$ increases, future oceans are growing warmer and lower in $\mathrm{pH}$ and oxygen, conditions that are likely to impact planktic communities. Past intervals of elevated and changing $p \mathrm{CO}_{2}$ and temperatures can offer a glimpse into the response of marine calcifying plankton to changes in surface oceans under conditions similar to those projected for the future. Here we present new records of planktic foraminiferal and coccolith calcification (weight and size) from Deep Sea Drilling Project Site 607 (mid-North Atlantic) and Ocean Drilling Program Site 999 (Caribbean Sea) from the Pliocene, the last time that $p \mathrm{CO}_{2}$ was similar to today, and extending through a global cooling event into the intensification of Northern Hemisphere glaciation (3.3 to 2.6 million years ago). Test weights of both surface-dwelling Foraminifera Globigerina bulloides and thermocline-dwelling Foraminifera Globorotalia puncticulata vary with a potential link to regional temperature variation in the North Atlantic, whereas in the tropics Globigerinoides ruber test weight remains stable. In contrast, reticulofenestrid coccoliths show a narrowing size range and a decline in the largest lith diameters over this interval. Our results suggest no major changes in plankton calcite production during the high $p \mathrm{CO}_{2}$ Pliocene or during the transition into an icehouse world.
\end{abstract}

\section{Introduction}

Over the last $250 \mathrm{yr}$ atmospheric $p \mathrm{CO}_{2}$ levels have increased from pre-industrial (pre-1750) levels of 280 parts per million (ppm) to 393 ppm in 2012 (Dlugokencky and Tans, 2013). As a consequence, the future ocean is predicted to be warmer, more acidic and oxygen poorer (Solomon et al., 2007). The environmental impacts of anthropogenic atmospheric $p \mathrm{CO}_{2}$ and resultant climatic changes are predicted to be widespread across all ecosystems with potential influences on biogeochemical cycles and ecosystem services (Turley et al., 2010). Previous research has largely focused on documenting the response of marine calcifiers to environmental parameters in laboratory culture experiments (Spero et al., 1997; Bijma et al., 1999; Riebesell et al., 2000; Langer et al., 2006; Iglesias-Rodriguez et al., 2008). In the natural environment, however, the plasticity within the population, the selection of ecophenotypes and genotypes with different environmental preferences, their migration, adaptation and evolution are possible mechanisms which may act to dampen the effect of ocean acidification on marine organisms and the processes they influence. Laboratory culture experiments therefore incompletely represent whole ecosystem responses to environmental change.

In contrast, marine sediments provide a record of past environmental perturbations in natural environments with their associated complexity, thereby allowing assessment of the potential for marine organisms to migrate, acclimatize and/or adapt to changing environmental conditions. Importantly, the geological record allows upscaling from experiments on single specimens or strains to large-scale ecosystem changes and their associated biogeochemical impacts.

Coccolithophores and foraminifers are key groups in the marine ecosystem and carbon cycle, together contributing the 
majority of pelagic carbonate production (Schiebel, 2002). Surface ocean temperature and $\mathrm{pH}$ have been shown to affect the physiology and ecology of both Foraminifera (Bé and Tolderlund, 1971; Hemleben et al., 1989; Bijma et al., 1990; Schmidt et al., 2004a) and coccolithophores (Gibbs et al., 2004; Thierstein and Young, 2004; Zondervan, 2007) and their calcification both in laboratory cultures and field studies (Bijma et al., 1999; Barker and Elderfield, 2002; Langer et al., 2006, 2009; de Moel et al., 2009; Beaufort et al., 2011). In coccoliths, the response, however, is strongly strain- and species-specific (Langer et al., 2006, 2009, 2011; Ridgewell et al., 2009), and the experiments are often short term with few exceptions (Lohbeck et al., 2012). These multi-generation experiments demonstrate the potential for selection of genotypes with differing environmental tolerances, and adaptation and evolution on relatively short timescales (500 generations). It has been argued that high $\mathrm{CO}_{2}$ in the future will result in smaller and less calcified coccoliths and lighter foraminifer tests; however larger cells supported by higher $\mathrm{CO}_{2}$ lead in a few cases to an overall increase in lith size under high atmospheric $p \mathrm{CO}_{2}$ conditions (Iglesias-Rodriguez et al., 2008). In coccolithophores size changes in response to varying bicarbonate ion and proton concentrations, changes in weight are proportional to changes in size (Bach et al., 2012). For planktic Foraminifera, species-specific relationships appear to exist between $\left[\mathrm{CO}_{3}^{=}\right]$and weight, but previous culture work supports a general trend of lighter shells under high $p \mathrm{CO}_{2}$ conditions (Bijma et al., 1999, 2002; Russell et al., 2004; Manno et al., 2012).

Surface ocean carbonate chemistry has remained remarkably constant over the recent evolutionary history of modern plankton (Hönisch et al., 2012) with typical surface ocean variations between glacials and interglacials of no more than $0.2 \mathrm{pH}$ units (Hönisch and Hemming, 2005; Foster, 2008). We therefore focus on deeper time records to test the effect of warmer, lower $\mathrm{pH}$ oceans on calcifying plankton. The Pliocene is the most recent epoch with atmospheric $p \mathrm{CO}_{2}$ levels (around $380-415 \mathrm{ppm}$ ) consistently above preindustrial levels but with continental placement and vegetation similar to modern times. Additionally, the Pliocene currently has the most robust reconstruction of atmospheric $p \mathrm{CO}_{2}$ compared to any other time in the pre-Pleistocene record (Pagani et al., 2010; Seki et al., 2010; Bartoli et al., 2011; Badger et al., 2013). As this time interval is relatively recent, we are able to utilize extant species or their near relatives in our study. Our study encompasses the end of the Pliocene warm period ( $\sim 3.3$ to $3.0 \mathrm{Ma})$ and the subsequent interval of global cooling culminating at $\sim 2.6 \mathrm{Ma}$, in the intensification of Northern Hemisphere glaciation (Ravelo et al., 2004).

We assess potential changes in the abundance and weight and size of planktic foraminifers and coccolithophores, zooplankton and phytoplankton respectively. We utilize two sites: one from the tropics and one from the mid-latitudes,
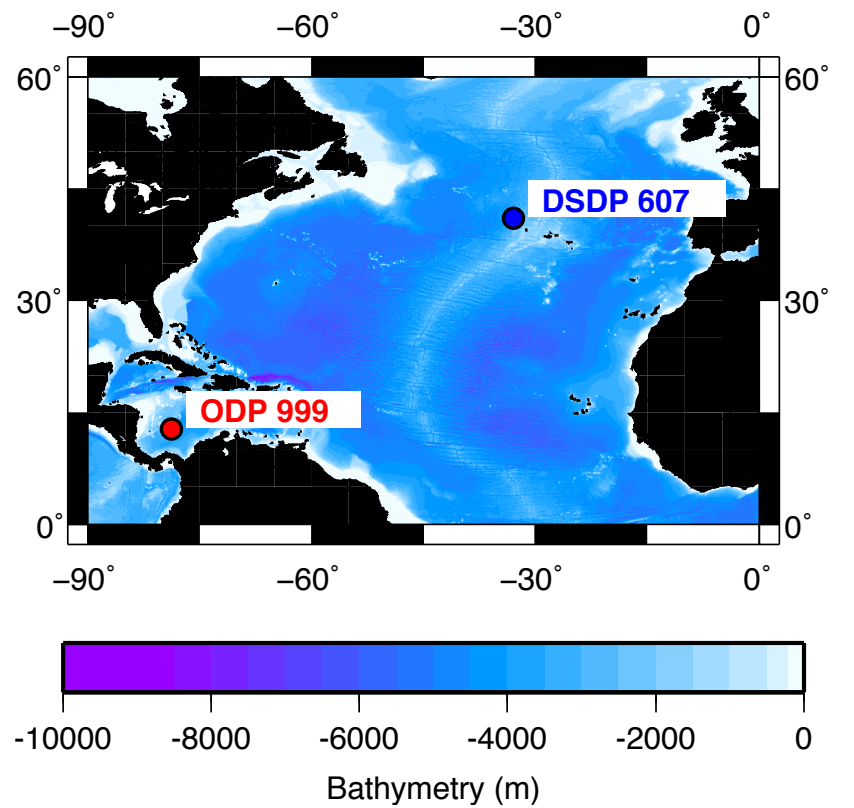

Fig. 1. Location map of study sites DSDP Site 607 (blue) and ODP Site 999 (red): bathymetry is from Amante and Eakins (2009). The same colour-coding for both sites will be used in all the following figures.

which share little in common in terms of their hydrology and nutrient regimes that could potentially overprint a synchronous $p \mathrm{CO}_{2}$ signal. Changes in atmospheric $p \mathrm{CO}_{2}$ should have a synchronous effect across most of the world's surface oceans while temperature changes will be more accentuated in the higher latitudes than in the tropics (Lawrence et al., 2009), thereby allowing us to address the relative importance of these synergistic factors. Furthermore, the latitudinal gradient between the sites allows the comparison of species with different biogeographic adaptation.

\section{Materials and methods}

Sediments were taken from Deep Sea Drilling Project (DSDP) Site 607 in the mid-North Atlantic $\left(41^{\circ} 00^{\prime} \mathrm{N}\right.$, $32^{\circ} 57^{\prime} \mathrm{W} ; 3426 \mathrm{~m}$ water depth) and from Ocean Drilling Program (ODP) Site 999 in the Caribbean Sea $\left(12^{\circ} 45^{\prime} \mathrm{N}\right.$, $78^{\circ} 44^{\prime} \mathrm{W}$; $2828 \mathrm{~m}$ water depth; Fig. 1). The age models for both sites were calculated from Lisiecki and Raymo's LR04 benthic Foraminifera-derived global $\delta^{18} \mathrm{O}$ stack (Lisiecki and Raymo, 2005) and were used to calculate linear sedimentation rates and mass accumulation rates (MARs).

Calcium carbonate $\left(\mathrm{CaCO}_{3}\right)$ MARs, an indication of carbonate production in the surface waters, were calculated from shipboard observations of $\mathrm{CaCO}_{3}$ content, density and water content (Shipboard Scientific Party, 1997), while planktic foraminiferal mass accumulation rates (FMARs) were calculated from the bulk MARs and the sand fraction 
of the sediment, which consists predominantly of planktic foraminifers, and only a small number $(<1 \%)$ of benthic foraminifers. Changes in the relative contribution of foraminifers to coccolithophores to sediment production were calculated by dividing FMARs by carbonate MAR.

Sediment samples were washed over a $63 \mu \mathrm{m}$ sieve and dry-sieved at $150 \mu \mathrm{m}$. In each sample, at least 150 tests and test fragments (defined as any test with visible damage to at least two chambers or entirely lacking at least one chamber) were counted from the $>150 \mu \mathrm{m}$ size fraction as a measure of dissolution and an indicator of preservation (Berger, 1968, 1970). Sea surface temperature (SST) data were taken from Naafs et al. (2010) for Site 607, Groeneveld (2005) and Badger et al. (2013) for Site 999. Additional SST data from 2.6 to $2.8 \mathrm{Ma}$ were generated following the procedures detailed in Badger et al. (2013).

Relative changes in average foraminiferal test weight can be interpreted as changes in test thickness and the extent of calcification (Barker, 2002; Barker et al., 2003). Therefore, between 10 and 30 Foraminifera of Globigerina bulloides and Globorotalia puncticulata at Site 607 and Globigerinoides ruber at Site 999 were picked from the 300$355 \mu \mathrm{m}$ size fraction and size-normalized following the protocol in Barker (2002). Gs. ruber specimens were picked to reflect sensu stricto specimens, excluding kummerform and sensu lato specimens as these are known to have different habitats (Steinke et al., 2005) and therefore potentially different reactions to environmental drivers. For each sample, Foraminifera were weighed on a six-point Sartorius MC5 microbalance to obtain a population average weight. A total of 63 populations of G. bulloides, 52 of G. punitculata and 70 of Gs. ruber were analysed. G. punticulata was largely absent in the North Atlantic prior to 3.23 Ma (Lutz, 2011) and was not found in significant numbers. Error was estimated by repeat measurements of eight $G$. bulloides populations - three of which were re-picked from the original sample and another five reweighed. The error ranged from 2.58 to $2.32 \mu \mathrm{g}$, which is in line with the error of the balance $( \pm 2 \mu \mathrm{g})$.

The average diameter of each specimen in the same orientation was measured from digital images using ImageJ. A sample average test length was calculated to allow size normalization. Weighed populations of G. punticulata were not size-normalized due to the greater uncertainty in estimating volume from external measurements given the high variability of how conical individual tests are (see Barker, 2002, for discussion on the morphologically similar species $G$. inflata). For each sample, the size of all flat-lying reticulofenestrid liths from the $<63 \mu \mathrm{m}$ fraction, made up almost exclusively of coccoliths, was measured on a strew slide using a Hitachi S-3500N scanning electron microscope (SEM). Between 82 and 178 liths in each sample were imaged and the maximum diameter measured using ImageJ.

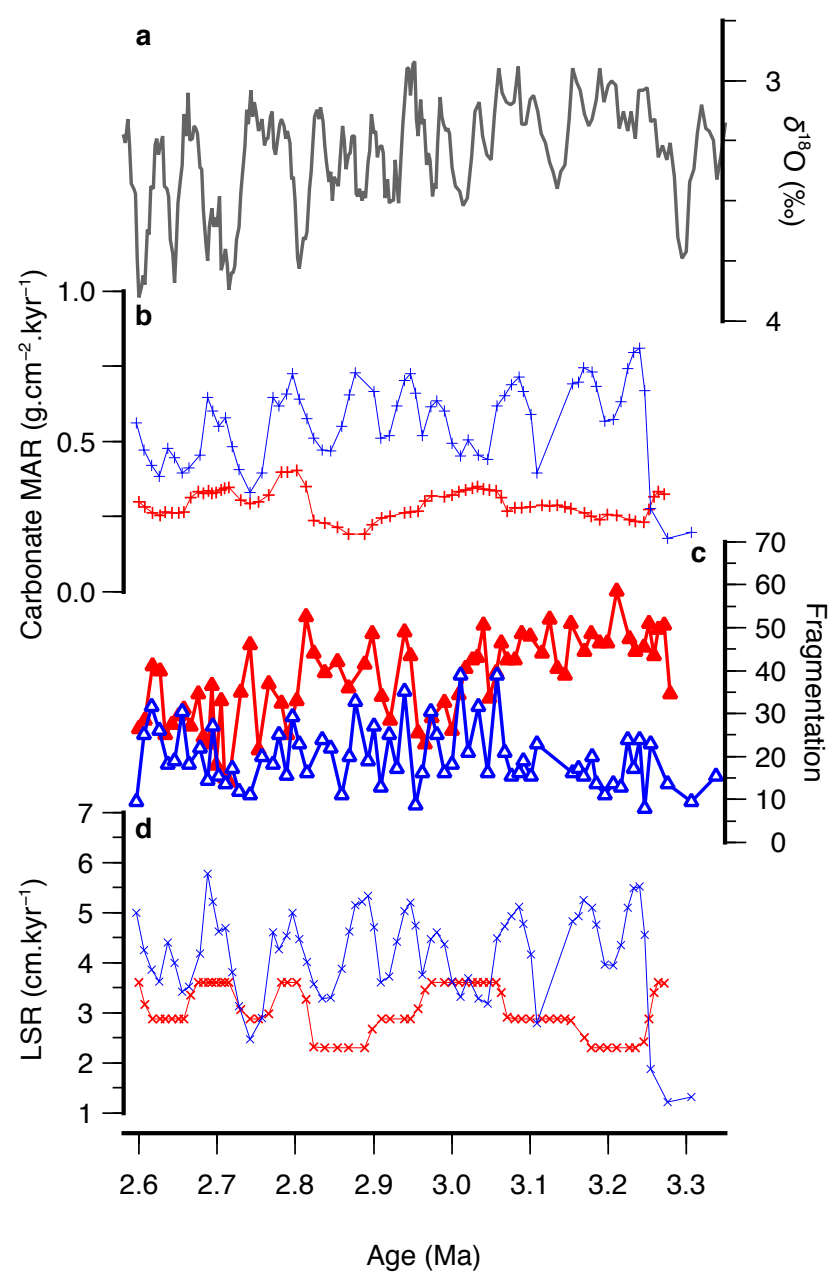

Fig. 2. (a) Benthic Foraminifera oxygen isotope $\left(\delta^{18} \mathrm{O}(\%)\right)$ stack (LR04; Lisiecki and Raymo, 2005), (b) carbonate mass accumulation rate (MAR, $\mathrm{g} \mathrm{cm}^{-2} \mathrm{kyr}^{-1}$ ), (c) planktic Foraminifera fragmentation (whole to fragment index, high values indicating more dissolution) and (d) linear sedimentation rates (LSRs, $\mathrm{cm} \mathrm{kyr}^{-1}$ ) calculated from LR04-based age models and shipboard physical properties. For all panels, red represents ODP Site 999 and blue DSDP 607.

\section{Results}

Carbonate MARs are nearly twice as high at Site 607 compared to at Site 999 (Fig. 2b). There is an orbital variability in the carbonate MARs at Site 607 while, in contrast, at Site 999 the carbonate MAR is more stable, in line with less environmental variability. Test fragmentation does not change significantly at Site 607 with an average value of $16.3 \% \pm 4.8 \%(1 \sigma)$, indicating consistently good preservation, consistent with the Shipboard Report (Fig. 3, Shipboard Scientific Party, 1987). In contrast, at Site 999 fragmentation decreases from $40-60 \%$ (at $3.0 \mathrm{Ma}$ ) to $20-40 \%$ (at $2.6 \mathrm{Ma}$ ) potentially caused by bottom water changes related to the final closure of the Central American Seaway 
(CAS) (Haug et al., 2001). At neither site did fragmentation couple with the foraminiferal / coccolithophores ratio, which we therefore deem to be influenced by differing abundances of these two calcifiers and not by preferential dissolution of foraminifers.

The foraminiferal contribution to the sediment is small at both sites, with $24 \mathrm{wt} \%$ at Site 999 and $8 \mathrm{wt} \%$ at Site 607 (Fig. 3g). While FMARs are variable $(0.050$ to $0.240 \mathrm{~g} \mathrm{~cm}^{-2} \mathrm{kyr}^{-1}$ at Site $999,0.016$ to $0.109 \mathrm{~g} \mathrm{~cm}^{-2} \mathrm{kyr}^{-1}$ at Site 607), there is no consistent trend over our studied interval. The relative importance of foraminifers to the carbonate production increases from 2.7 Ma onwards at Site 607, while there is no change at Site 999.

Foraminiferal weight ranges from 13.4 to $22.4 \mu \mathrm{g}$ for G. bulloides, 15.7 to $21.1 \mu \mathrm{g}$ for Gs. ruber, and 24.8 to $40.9 \mu \mathrm{g}$ for G. puncticulata (Fig. 3d, e). Unexpectedly, the deep dweller $G$. puncticulata shows significantly higher weight variability than the surface dweller. At Site 999 at 2.7 Ma, Gs. ruber weight drops, which cannot be due to dissolution as preservation is improving. In contrast, at Site 607 there is no overall change in weight throughout the record.

Average coccolith size is stable at Site 607, while at Site 999 average lith size increases towards $3 \mathrm{Ma}$, is high from 2.94 to $2.80 \mathrm{Ma}$ and drops thereafter - the increase between 2.94 and $2.80 \mathrm{Ma}$ being driven by an increase in the number of liths larger than $5 \mu \mathrm{m}$ (Fig. 3b, c). It is important to note though that Site 607 records a strong variability of relative contribution of large liths and a clear loss of those large liths from 2.7 Ma.

\section{Discussion}

Coccolithophores and Foraminifera are both thought to respond to changes in atmospheric $p \mathrm{CO}_{2}$. This has raised concerns about the future of the alkalinity pump (Ridgwell and Zeebe, 2005), the export of carbonate from the surface ocean to the deep sea, and the effect of a change in carbonate ballasting on the efficiency of the biological pump (Klaas and Archer, 2002). Therefore, the prediction would be that the carbonate MAR should be lower in a high $p \mathrm{CO}_{2}$ world than today and that it would increase at the time of postulated drop in $p \mathrm{CO}_{2}$.

However, despite the environmental change associated with the intensification of Northern Hemisphere glaciation (Haug and Tiedemann, 1998), we see no clear shift in carbonate MAR. The largest signal in the carbonate MAR is not at the end of the Pliocene warm interval (Pagani et al., 2010; Seki et al., 2010) but across the glacial-interglacial changes most prominent at Site 607 and much larger than at Site 999 (Fig. 2). Overall carbonate MAR is higher at Site 607 compared to Site 999, which is unsurprising given the generally oligotrophic setting in the Caribbean (Jain and Collins, 2007), and the higher productivity at the higher latitude site (Behrendfeld and Falkowski, 1997).
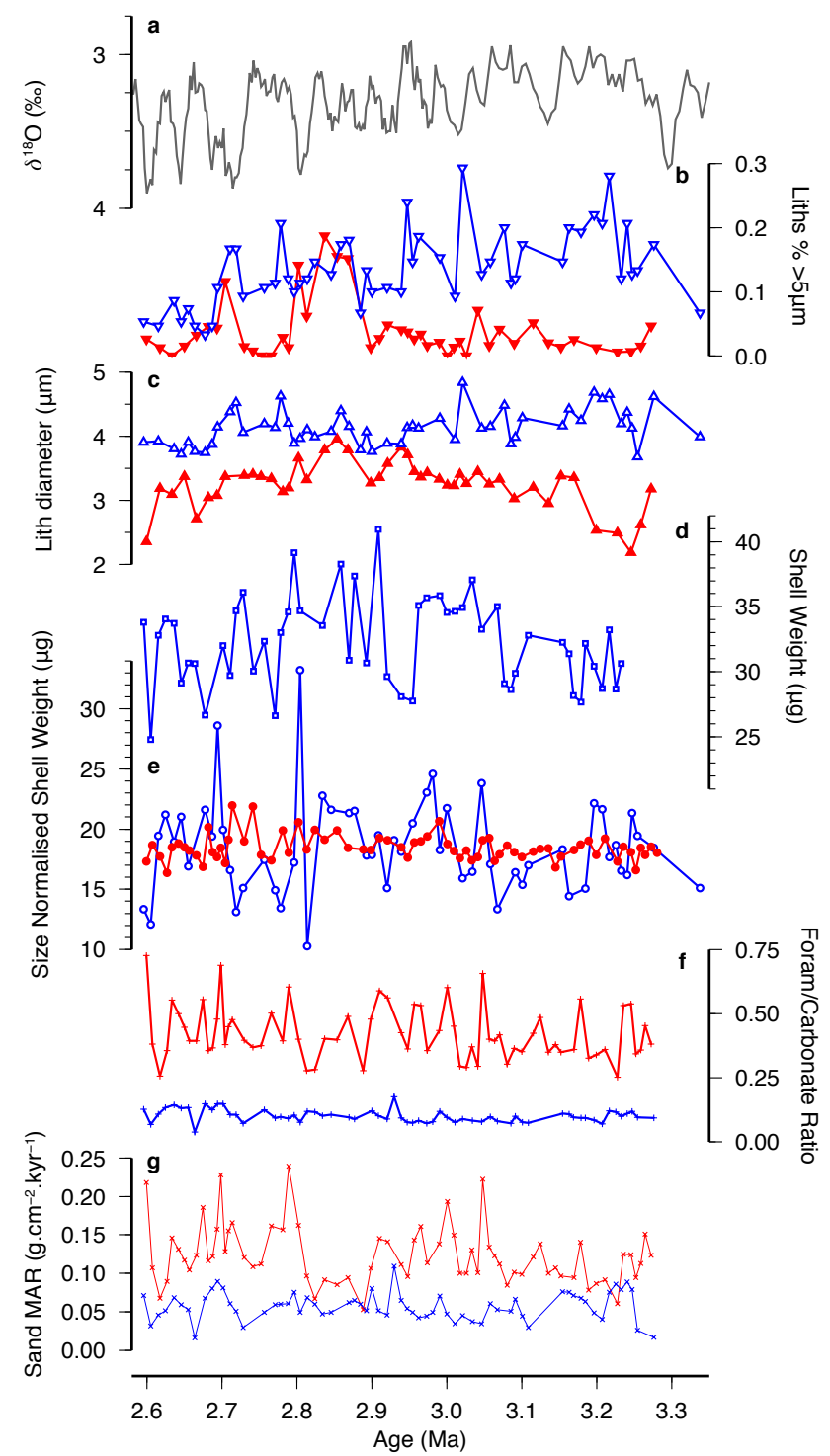

Fig. 3. (a) Benthic Foraminifera oxygen isotope $\left(\delta^{18} \mathrm{O}(\%)\right)$ stack (LR04; Lisiecki and Raymo, 2005), (b) percentage of measured lith with diameter greater than $5 \mu \mathrm{m}$, (c) average lith diameter, (d) thermocline dweller G. punticulata mean test weight, (e) sizenormalized test weight of the surface dwellers G. bulloides and Gs. ruber, (f) Foraminifera: carbonate ratio and (g) sand mass accumulation rate $\left(\mathrm{g} \mathrm{cm}^{-2} \mathrm{kyr}^{-1}\right)$. For all panels red represents ODP Site 999 and blue DSDP 607.

The contrasting records at these two distant sites suggest that local rather than global or regional drivers are responsible for the changes in MAR. As the surface ocean at both sites is near equilibrium with the atmosphere today (Takahashi et al., 2002, 2009; and there is no reason to think that this was not the case in the Pliocene), any atmospheric $p \mathrm{CO}_{2}$ change should affect both sites in the same way and with the same timing. In contrast, any changes arising from a local environmental effect such as SST (Fig. 4) would be muted 


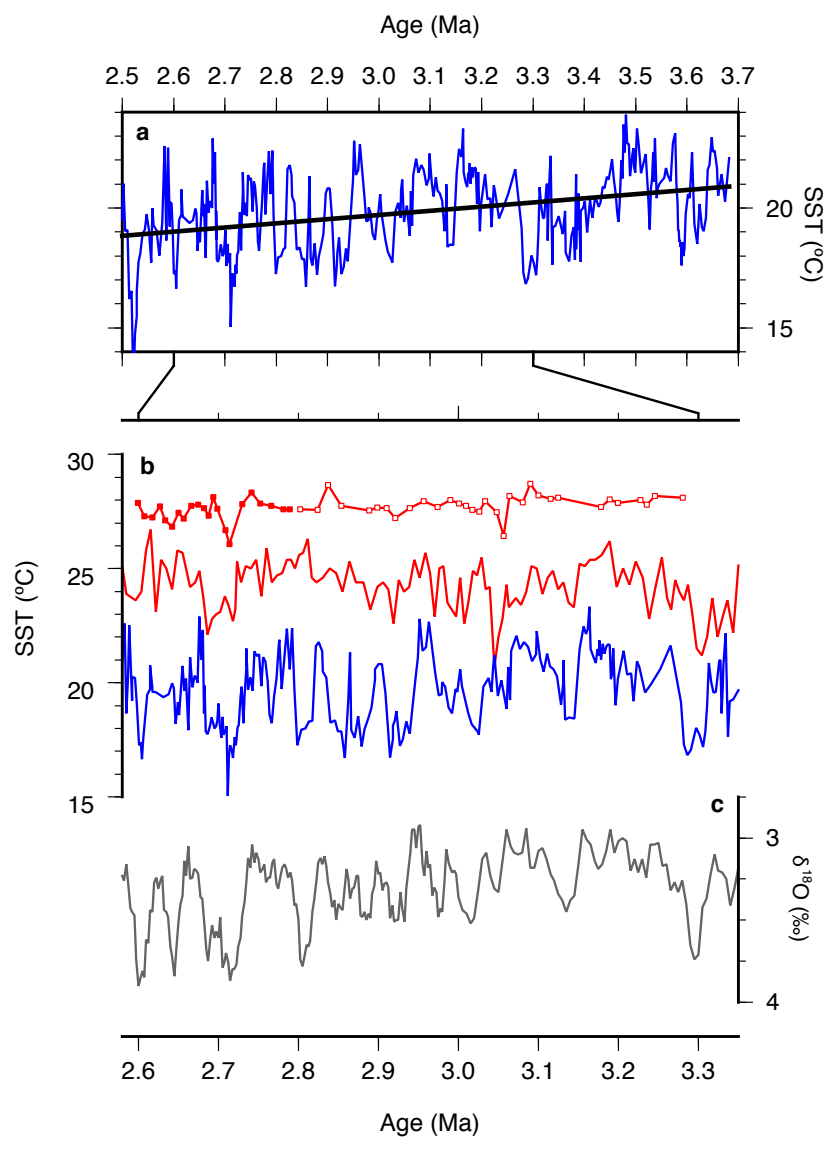

Fig. 4. (a) SST with linear trend line (Naafs et al., 2010) and (b) SST $\left({ }^{\circ} \mathrm{C}\right)$ records from alkenone unsaturation index from Naafs et al. (2010) (Site 607; blue line), Badger et al. (2013) (Site 999; red open squares and line), and this study (Site 999; red filled squares and line) and from $\mathrm{Mg} / \mathrm{Ca}$ ratio of Globigerinoides sacculifer (Groeneveld, 2005). For all panels red represents ODP Site 999 and blue DSDP Site 607 and (c) benthic Foraminifera oxygen isotope $\left(\delta^{18} \mathrm{O}\right.$ (\%o)) stack (LR04; Lisiecki and Raymo, 2005)

in the Caribbean $\left(\sim 23-25^{\circ} \mathrm{C}\right.$, Groeneveld, 2005) compared with the North Atlantic $\left(\sim 17-22^{\circ} \mathrm{C}\right.$, Naafs et al., 2010), and this is what we in fact see. While it is tempting to compare the differences in $p \mathrm{CO}_{2}$ change between glacial and interglacials in the Pliocene and the late Pleistocene $(\sim 40 \mathrm{ppm}$, Badger et al., 2013 vs. $\sim 100$ ppm, Siegenthaler et al., 2005), and the amplitude of changes in carbonate production, there are many other factors, such as temperature, stratification and nutrient availability, that will be influenced by the same forcing, making a direct comparison difficult. Also, while $p \mathrm{CO}_{2}$ and SST are globally tightly coupled, at Site 607 the migration of the North Atlantic Current and the northern extent of the subtropical gyre will likely amplify the response (Naafs et al., 2010).

We cannot rule out an influence of either bottom water saturation state or pore water saturation state on foraminiferal test weight, the former of which has been shown to have a significant impact in past studies (Lohman et al., 1995). Fragmentation of foraminifer tests suggests a consistent state of preservation for carbonate sediments at Site 607 but an improvement of preservation around $\sim 2.8 \mathrm{Ma}$ at Site 999 . At Site 607, given that there is no indication of changes in the degree of dissolution through our study interval, samples in this core are likely not impacted by changing dissolution. However, it is possible that the observed preservation changes at Site 999 may have an effect on the record. If such an influence were taken into account, this would make shell weight even lighter after $\sim 2.8 \mathrm{Ma}$, not heavier as would be expected if foraminiferal weight were following $p \mathrm{CO}_{2}$. Thus, the impacts of changes in pore water and/or bottom water saturation state on test weight do not influence our interpretation of the weight records at Sites 607 and 999.

Foraminifera make up a minor proportion of carbonate production by mass, and the $\sim 3$ times higher wt $\%$ at Site 999 is likely due to the larger species present (Schmidt et al., 2004a, 2006) and their higher overall mass. At Site 999, foraminiferal weights are surprisingly stable and show no significant variation across any environmental changes, including the closure of the CAS. At Site 607, G. bulloides weight changes by around one-third, associated with glacialinterglacial cycles; similar variability in test weight is seen through the Pleistocene glacial-interglacial cycles at a similar location and related to $p \mathrm{CO}_{2}$ forcing (Barker and Elderfield, 2002; Moy et al., 2009). Absolute test weights and range of test weight in North Atlantic Pliocene and Pleistocene $G$. bulloides are similar despite the higher $p \mathrm{CO}_{2}$ during the Pliocene. Interestingly though, the weights found in the sediment samples in the Moy et al. (2009) study (though not their trap data) are significantly higher than in our data or the Barker and Elderfield (2002) study for the same species.

Given the predicted smaller $p \mathrm{CO}_{2}$ variability between Pliocene glacial-interglacial cycles compared to the Pleistocene, we would have expected smaller foraminiferal test weight changes in the Pliocene (half the magnitude observed here), if this were the main or even sole driver. We would also expect to see changes at both sites of similar magnitude if global $p \mathrm{CO}_{2}$ were the main driver. As for the carbonate MAR data, the contrasting records at these two sites suggest that regional drivers are responsible for the changes in test weight and not changes in $p \mathrm{CO}_{2}$. The magnitudes of temperature change during the Pliocene at Site 607 and Pleistocene at Site NEAP 8K of Barker and Elderfield (2002) were similar, while the temperature in the Caribbean during the Pliocene was very stable. The large glacial-interglacial temperature difference of $\sim 6^{\circ} \mathrm{C}$ at Site 607 is plausibly the result of the proximity to the North Atlantic Current, as mentioned above. Changes in temperature and frontal dynamics influence the growth of planktic foraminifers, with smaller individuals growing under less optimal conditions due to the environmental variability close to frontal systems (Schmidt et al., 2003). The effect of the frontal system on thermocline structure at Site 607 may also be the cause of the higher 
test weight variability in the thermocline-dwelling G. punticulata, which is greater than the surface dweller G. bulloides. Changes in thermocline structures have been shown to influence planktic foraminiferal growth, with larger sizes in more stratified waters (Schmidt et al., 2004b). Weight changes at both sites could also be due to the presence of changing abundances of cryptic species within established species, as are known to exist for modern North Atlantic G. bulloides (Darling and Wade, 2008)

The overall reaction of coccolithophores to these environmental changes is difficult to predict due to the wide range of responses to multiple forcings, including ocean acidification (Langer et al., 2006; Ridgwell et al., 2009; Beaufort et al., 2011). Additionally, the average reticulofenestrid coccolith size within an assemblage reflects the diversity of species, strains and/or phenotypic variability within populations, all of which may have their own environmental preferences. Carbonate chemistry seems to influence the ecology of coccolithophores and alter species and morphotype abundance in the ocean (Beaufort et al., 2011). Coccolith size may therefore reflect a complex interplay of extinction, migration and size changes within the population.

In general, the Pliocene is an interval of relatively high evolutionary turnover in coccolithophores (Bown, 2005). There are at least four Discoaster extinctions (Gibbs et al., 2004) indicating significant changes within the nanoplankton communities, but these do not directly impact our data, which solely represent the dominant taxa, the reticulofenestrids. The different size trends seen at the two sites represent different proportions of species/genotypes/ecophenotypes in the reticulofenestrid populations (e.g. as seen in Young and Westbroek, 1991; Renaud, et al., 2002), but these are relatively subtle shifts, which generally fall below the resolution of traditional taxonomic groupings. Hence their relationship with environmental change is uncertain. It is likely that these trends reflect a trend in turnover, not dissolution, because fragmentation is relatively stable across the record at Site 607 and improves at Site 999 when large liths, which are less prone to dissolution, disappear (Fig. 2).

The overall trend towards smaller liths through the Pliocene into the Quaternary has been previously documented and linked to species turnover and extinction events (Young, 1990; Gibbs et al., 2005). A decline in the larger reticulofenestrid coccoliths similar to that which we find at Site 607 has also been observed in the Atlantic, Pacific, Indian and Arctic oceans (Young, 1990; Sato and Kameo, 1996; Kameo and Takayama, 1999; Kameo and Bralower, 2000; Sato et al., 2002). This trend cannot be driven by the extinction of the largest $(>7 \mu \mathrm{m})$ reticulofenestrids (Reticulofenestra pseudoumbilicus) as this occurred just prior to our study interval, at 3.7 Ma. Other more subtle but discrete events, such as the disappearance of reticulofenestrid coccoliths $>5 \mu \mathrm{m}$ (Reticulofenestra ampla of Sato et al., 1991), are seen at Site 607 around $\sim 2.7 \mathrm{Ma}$, and the global nature of this trend suggests that these are widespread evolutionary changes. Evolution, changes in abundance, and extinctions within large-sized genera, such as Calcidiscus, Coccolithus, Helicosphaera, and Reticulofenestra, and the rise of small-coccolith-producing taxa, such as Emiliania and Gephyrocapsa, have been linked to size changes in coccolithophore assemblages (Herrmann et al., 2012). In contrast, the size record at the Caribbean Site 999 is dominated by a short-lived increase in larger liths $(>5 \mu \mathrm{m})$ between 2.8 and 3.0 Ma, and may represent a migration event into the Caribbean. The predicted change in $p \mathrm{CO}_{2}$ clearly does not influence the lith size in reticulofenestrids, and the size difference between the Caribbean (smaller liths) and North Atlantic (larger liths) presumably reflects different ecological preferences within the small- to medium-sized reticulofenestrids.

The brief influx of large specimens in the Caribbean could reflect the complex environmental change in the area during the final stages of the closure of the CAS, but again this is not time-equivalent with the suggested changes in $p \mathrm{CO}_{2}$. The final closure of the CAS has been suggested to have occurred at 2.7 Ma (Bartoli et al., 2005; Schmidt, 2007), which coincides with the first major glaciation of the Plio-Pleistocene at $2.73 \mathrm{Ma}$ (Lisiecki and Raymo, 2005) and a number of changes in our biotic records. The loss of large reticulofenestrid coccolithophores in the North Atlantic, a relative increase of Foraminifera as carbonate producers at the same site, and a minor reduction of foraminiferal weight in the Caribbean all suggest significant changes in the North Atlantic in general. The convergence of the lith records might suggest that the environments at both sites became more similar and may be linked to an increase in warm-water transport to the north due to the closure of the shallow-water throughflow (Haug et al., 2001) or to increased vertical stratification in high latitudes (Sigman et al., 2004).

One key difference that must be noted in any attempt to compare these results from the Pliocene with modern oceans is that the rate of $p \mathrm{CO}_{2}$ change was much lower than at present, a difference which could affect both any potential adaptive responses and the potential for decoupling of $\mathrm{pH}$ and saturation state in the Pliocene. Thus, while proxy records may clearly indicate both a greater than pre-industrial atmospheric $p \mathrm{CO}_{2}$ and lower $\mathrm{pH}$, saturation state may not have been significantly changed (Hönisch et al., 2012). This latter parameter is especially important in the interpretation of foraminiferal weight as it is the $\left[\mathrm{CO}_{3}^{=}\right]$specifically that has been implicated in driving changes in test weight.

\section{Conclusions}

The drop in $p \mathrm{CO}_{2}$ at the end of the Pliocene had no effect on carbonate mass accumulation, reticulofenestrid coccolith size or foraminiferal weight. Sea surface temperature or related environmental parameters, some of which might 
be linked to the closure of the central tropical seaways, appear to have a larger effect on planktic carbonate producers than $p \mathrm{CO}_{2}$ alone during the Pliocene. While these environmental changes may not be forcing critical stress on either plankton group (in terms of evolution or extinction events), they may be causing organisms to adjust their biogeographical distribution to suit environmental tolerances (e.g. Renaud and Schmidt, 2003). Both groups of organisms adapted to the environmental changes during the Pliocene, including the higher $p \mathrm{CO}_{2}$ levels that are comparable to those predicted for the next decades, as well as the onset of more intense glaciations. We suggest that rates of change, via a link to migration rates and generation time, rather than absolute $p \mathrm{CO}_{2}$ values, might drive a calcification response in these groups.

\section{Supplementary material related to this article is available online at http://www.biogeosciences.net/10/ 6131/2013/bg-10-6131-2013-supplement.pdf.}

Acknowledgements. This research used samples and data provided by the Ocean Drilling Program, which is sponsored by the US National Science Foundation and participating countries under the management of Joint Oceanic Institutions. This research was funded by NERC grant NE/H006273/1, DNS by a Royal Society URF. We thank Marilyn Potts for lab work and are grateful to Kirsty Edgar for comments on an early draft of the manuscript. We warmly thank the reviewers and the editor, Ulf Riebesell, for constructive comments which greatly improved the manuscript.

Edited by: U. Riebesell

\section{References}

Amante, C. and Eakins, B. W.: ETOPO1 1 Arc-Minute Global Relief Model: Procedures, Data Sources and Analysis, NOAA Technical Memorandum NESDIS NGDC-24, 19 pp., March 2009.

Bach, L. T., Bauke, C., Meier, K. J. S., Riebesell, U., and Schulz, K. G.: Influence of changing carbonate chemistry on morphology and weight of coccoliths formed by Emiliania huxleyi, Biogeosciences, 9, 3449-3463, doi:10.5194/bg-9-3449-2012, 2012.

Badger, M. P. S., Schmidt, D. N., Mackensen, A., and Pancost, R. D.: High resolution alkenone palaeobarometry indicates relatively stable pCO2 during the Pliocene (3.3 to $2.8 \mathrm{Ma}$ ), Philos. T. R. Soc. A, 2013, 371, 20130094, doi:10.1098/rsta.2013.0094, 2013

Barker, S.: Planktonic foraminiferal proxies for temperature and $\mathrm{CO}_{2}$, Cambridge University Press, Cambridge, 2002.

Barker, S. and Elderfield, H.: Foraminiferal calcification response to glacial-interglacial changes in atmospheric $\mathrm{CO}_{2}$, Science, 297, 833-836, 2002.

Barker, S., Higgins, J. A., and Elderfield, H.: The future of the carbon cycle: review, calcification response, ballast and feedback on atmospheric $\mathrm{CO}_{2}$, Philos. T. R. Soc. Lond., 361, 1977-1999, 2003.

Bartoli, G., Sarnthein, M., Weinelt, M., Erlenkeuser, H., GarbeSchönberg, D., and Lea, D. W.: Final closure of Panama and the onset of Northern Hemisphere glaciation, Earth Planet. Sc. Lett., 237, 33-44, 2005.

Bartoli, G., Hönisch, B., and Zeebe, R. E.: Atmospheric $\mathrm{CO}_{2}$ decline during the Pliocene intensification of Northern Hemisphere glaciations, Paleoceanography, 26, PA4213, doi:10.1029/2010pa002055, 2011.

Bé, A. W. H. and Tolderlund, D. S.: Distribution and ecology of living planktonic foraminifera in surface waters of the Atlantic and Indian Oceans, in: Micropaleontology of Marine Bottom Sediments, edited by: Funnell, B. M. and Riedel, W. R., Cambridge University Press, Cambridge, 105-149, 1971.

Beaufort, L., Probert, I., de Garidel-Thoron, T., Bendif, E. M., RuizPino, D., Metzl, N., Goyet, C., Buchet, N., Coupel, P., Grelaud, M., Rost, B., Rickaby, R. E. M., and de Vargas, C.: Sensitivity of coccolithophores to carbonate chemistry and ocean acidification, Nature, 476, 80-83, 2011.

Behrendfeld, M. J. and Falkowski, P. G.: Photosynthetic rates derived from satellite-based chlorophyll concentrations, Limnol. Oceanogr., 42, 1-20, 1997.

Berger, W. H.: Planktonic foraminifera selective solution and paleoclimatic interpretation, Deep-Sea Res., 15, 31-41, 1968.

Berger, W. H.: Planktonic foraminifera: selective solution and the lysocline, Mar. Geol., 8, 111-138, 1970.

Bijma, J., Faber, W. W., and Hemleben, C.: Temperature and salinity limits for growth and survival of some planktonic foraminifers in laboratory cultures, J. Foramin. Res., 20, 95-116, 1990.

Bijma, J., Spero, H. J., and Lea, D. W.: Reassessing foraminiferal stable isotope geochemistry: impact of the oceanic carbonate system (experimental results), in: Use of Proxies in Paleoceanography: Examples from the South Atlantic, edited by: Fischer, G. and Wefer, G., Springer, Berlin, 489-512, 1999.

Bijma, J., Honisch, B., and Zeebe, R. E.: Impact of the ocean carbonate chemistry on living foraminiferal shell weight: Comment on "Carbonate ion concentration in glacial-age deep waters of the Caribbean Sea" by Broecker, W. S. and Clark, E., Geochem. Geophy. Geosy., 3, 1064, doi:10.1029/2002GC000388, 2002.

Bown, P. R.: Calcareous nannoplankton evolution: a tale of two oceans, Micropaleontology, 51, 299-308, doi:10.2113/gsmicropal.51.4.299, 2005.

Darling, K. F. and Wade, C. M.: The genetic diversity of planktic foraminifera and the global distribution of ribosomal RNA genotypes, Mar. Micropaleontol., 67, 216-238, doi:10.1016/j.marmicro.2008.01.009, 2008.

de Moel, H., Ganssen, G. M., Peeters, F. J. C., Jung, S. J. A., Kroon, D., Brummer, G. J. A., and Zeebe, R. E.: Planktic foraminiferal shell thinning in the Arabian Sea due to anthropogenic ocean acidification?, Biogeosciences, 6, 1917-1925, doi:10.5194/bg-6-1917-2009, 2009.

Dlugokencky, E. and Tans, P. P.: Recent Mauna Loa $\mathrm{CO}_{2}$, available at: http://www.esrl.noaa.gov/gmd/ccgg/trends/, last access: 25 March 2013.

Foster, G. L.: Seawater $\mathrm{pH}, p \mathrm{CO}_{2}$ and $\left[\mathrm{CO}_{2}-3\right]$ variations in the Caribbean Sea over the last 130 kyr: a boron isotope and B/Ca study of planktic foraminifera, Earth Planet. Sc. Lett., 271, 254 266, 2008 
Gibbs, S. J., Shackleton, N., and Young, J. R.: Orbitally forced climate signals in mid-Pliocene nannofossil assemblages, Mar. Micropaleontol., 51, 39-56, 2004.

Gibbs, S. J., Young, J. R., Bralower, T. J., and Shackleton, N. J.: Nannofossil evolutionary events in the mid-Pliocene: an assessment of the degree of synchrony in the extinctions of Reticulofenestra pseudoumbilicus and Sphenolithus abies, Paleogeogr. Paleocl., 217, 155-172, 2005.

Groeneveld, J.: Effect of the pliocene closure of the Panamanian Gateway on Caribbean and east Pacific sea surface temperatures and salinities by applying combined $\mathrm{Mg} / \mathrm{Ca}$ and $\delta^{18} \mathrm{O}$ measurements (5.6-2.2 Ma), Christian Albrechts University of Kiel, Kiel, 2005.

Haug, G. H. and Tiedemann, R.: Effect of the formation of the Isthmus of Panama on Atlantic Ocean thermohaline circulation, Nature, 393, 673-676, 1998.

Haug, G. H., Tiedemann, R., Zahn, R., and Ravelo, A. C.: Role of Panama uplift on oceanic freshwater balance, Geology, 29, 207210, 2001

Hemleben, C., Spindler, M., and Anderson, O. R.: Modern Planktonic Foraminifera, Springer, New York, Berlin, Heidelberg, 363 pp., 1989.

Herrmann, S., Weller, A. F., Henderiks, J., and Thierstein, H. R.: Global coccolith size variability in Holocene deep-sea sediments, Mar. Micropaleontol., 82, 1-12, 2012.

Hönisch, B. and Hemming, N. G.: Surface ocean $\mathrm{pH}$ response to variations in $p \mathrm{CO}_{2}$ through two full glacial cycles, Earth Planet. Sc. Lett., 236, 305-314, 2005.

Hönisch, B., Ridgwell, A., Schmidt, D. N., Thomas, E., Gibbs, S. J., Sluijs, A., Zeebe, R., Kump, L., Martindale, R. C., Greene, S. E., Kiessling, W., Ries, J., Zachos, J. C., Royer, D. L., Barker, S., Marchitto, T. M., Moyer, R., Pelejero, C., Ziveri, P., Foster, G. L., and Williams, B.: The geological record of ocean acidification, Science, 335, 1058-1063, doi:10.1126/science.1208277, 2012.

Iglesias-Rodriguez, M. D., Halloran, P. R., Rickaby, R. E. M., Hall, I. R., Colmenero-Hidalgo, E., Gittins, J. R., Green, D. R. H., Tyrrell, T., Gibbs, S. J., von Dassow, P., Rehm, E., Armbrust, E. V., and Boessenkool, K. P.: Phytoplankton calcification in a high- $\mathrm{CO}_{2}$ world, Science, 320, 336-340, doi:10.1126/science.1154122, 2008

Jain, S. and Collins, L. S.: Trends in caribbean paleoproductivity related to the neogene closure of the central american seaway, Mar. Micropaleontol., 63, 57-74, 2007.

Kameo, K. and Bralower, T. J.: Neogene calcareous nannofossil biostratigraphy of Site 998, 999, and 1000, Caribbean Sea, in: Proceedings of the Ocean Drilling Program, Scientific Results, edited by: Leckie, R. M., Sigurdsson, H., Acton, G. D., and Draper, G., Ocean Drilling Program, College Station, TX, 3-17, 2000.

Kameo, K. and Takayama, T.: Biostratigraphic significance of sequential size variations of the calcareous nannofossil genus Reticulofenestra in the Upper Pliocene of the North Atlantic, Mar. Micropaleontol., 37, 41-52, 1999.

Klaas, C. and Archer, D. E.: Association of sinking organic matter with various types of mineral ballast in the deep sea: implications for the rain ratio, Global Biogeochem. Cy., 16, 1116, doi:10.1029/2001GB001765, 2002.

Langer, G., Geisen, M., Baumann, K.-H., Kläs, J., Riebesell, U., Thoms, S., and Young, J. R.: Species-specific responses of calci- fying algae to changing seawater carbonate chemistry, Geochem. Geophys. Geosy., 7, Q09006, doi:10.1029/2005GC001227, 2006.

Langer, G., Nehrke, G., Probert, I., Ly, J., and Ziveri, P.: Strain-specific responses of Emiliania huxleyi to changing seawater carbonate chemistry, Biogeosciences, 6, 2637-2646, doi:10.5194/bg-6-2637-2009, 2009.

Langer, G. and Bode, M.: $\mathrm{CO}_{2}$ mediation of adverse effects of seawater acidification in Calcidiscus leptoporus, Geochem. Geophy. Geosy., 12, Q05001, 2011.

Lawrence, K. T., Herbert, T. D., Brown, C. M., Raymo, M. E., and Haywood, A. M.: High-amplitude variations in North Atlantic sea surface temperature during the early Pliocene warm period, Paleoceanography, 24, PA2218, doi:10.1029/2008PA001669, 2009.

Lisiecki, L. E. and Raymo, M. E.: A Pliocene-Pleistocene stack of 57 globally distributed benthic $\delta^{18} \mathrm{O}$ records, Paleoceanography, 20, PA1003, doi:10.1029/2004PA001071, 2005.

Lohbeck, K. T., Riebesell, U., and Reusch, T. B. H.: Adaptive evolution of a key phytoplankton species to ocean acidification, Nat. Geosci., 5, 346-351, 2012.

Lohmann, G. P.: A model for variation in the chemistry of planktonic foraminifera due to secondary calcification andselective dissolution, Paleoceanography, 10, 445-457, 1995.

Lutz, B. P.: Shifts in North Atlantic planktic foraminifer biogeography and subtropical gyre circulation during the midPiacenzian warm period, Mar. Micropaleontol., 80, 125-149, doi:10.1016/j.marmicro.2011.06.006, 2011

Manno, C., Morata, N., and Bellerby, R.: Effect of ocean acidification and temperature increase on the planktonic foraminifer Neogloboquadrina pachyderma (sinistral), Polar Biol., 1-9, doi:10.1029/2003GC000670, 2012.

Moy, A. D., Howard, W. R., Bray, S. G., and Trull, T. W.: Reduced calcification in modern southern ocean planktonic foraminifera, Nat. Geosci., 2, 276-280, doi:10.1038/ngeo460, 2009.

Naafs, B. D. A., Stein, R., Hefter, J., Khelifi, N., De Schepper, S., and Haug, G. H.: Late Pliocene changes in the North Atlantic Current, Earth Planet. Sc. Lett., 298, 434-442, doi:10.1016/j.epsl.2010.08.023, 2010.

Pagani, M., Liu, Z., LaRiviere, J., and Ravelo, A. C.: High Earthsystem climate sensitivity determined from Pliocene carbon dioxide concentrations, Nat. Geosci., 3, 27-30, 2010.

Ravelo, A. C., Andreasen, D. H., Lyle, M., Lyle, A. O., and Wara, M. W.: Regional climate shifts caused by gradual global cooling in the Pliocene epoch, Nature, 429, 263-267, 2004.

Renaud, S., Ziveri, P., and Broerse, A. T. C.: Geographical and seasonal differences in morphology and dynamics of the coccolithophore Calcidiscus leptoporus, Mar. Micropaleontol., 46, 363-387, 2002.

Ridgwell, A. and Zeebe, R. E.: The role of the global carbonate cycle in the regulation and evolution of the Earth system, Earth Planet. Sc. Lett., 234, 299- 315, 2005.

Ridgwell, A., Schmidt, D. N., Turley, C., Brownlee, C., Maldonado, M. T., Tortell, P., and Young, J. R.: From laboratory manipulations to Earth system models: scaling calcification impacts of ocean acidification, Biogeosciences, 6, 2611-2623, doi:10.5194/bg-6-2611-2009, 2009.

Riebesell, U., Zondervan, I., Rost, B., Tortell, R., Zeebe, R., and Morel, F. M. M.: Reduced calcification of marine plankton in 
response to increased atmospheric $\mathrm{CO}_{2}$, Nature, 407, 362-367, 2000.

Russell, A. D., Honisch, B., Spero, H. J., and Lea, D. W.: Effects of seawater carbonate ion concentration and temperature on shell $\mathrm{U}$, $\mathrm{Mg}$, and $\mathrm{Sr}$ in cultured planktonic foraminifera, Geochim. Cosmochim. Ac., 68, 4347-4361, 2004.

Sato, T. and Kameo, K.: Pliocene to Quaternary calcareous nannofossil biostratigraphy of the Arctic Ocean, with reference to late Pliocene glaciation, in: Proceedings of Ocean Drilling Program, Scientific Results, Leg 151, edited by: Thiede, J., Myhre, A. M., FirthG, J. V., Johnson, L., and Ruddiman, W. F., Ocean Drilling Program, College Station, 1996.

Sato, T., Saito, T., Yuguchi, S., Nakagawa, H., Kameo, K., and Takayama, T.: Late Pliocene calcareous nannofossil paleobiogeography of the Pacific Ocean: evidence for glaciation at 2.75 Ma, Rev. Mex. Cienc. Geol., 19, 175-189, 2002.

Schiebel, R.: Planktic foraminiferal sedimentation and the marine calcite budget, Global Biogeochem. Cy., 16, 1065, doi:10.1029/2001GB001459, 2002.

Schmidt, D. N.: The closure history of the Panama Isthmus: evidence from isotopes and fossils to models and molecules, in: Deep Time Perspectives on Climate Change - Marrying the Signal from Computer Models and Biological Proxies, Geological Society of London, London, 429-444, 2007.

Schmidt, D. N., Renaud, S., and Bollmann, J.: Response of planktic foraminiferal size to late Quaternary climate change, Paleoceanography, 18, 1039, doi:10.1029/2002PA000831, 2003.

Schmidt, D. N., Renaud, S., Bollmann, J., Schiebel, R., and Thierstein, H. R.: Size distribution of Holocene planktic foraminifer assemblages: biogeography, ecology and adaptation, Mar. Micropaleontol., 50, 319-338, 2004a.

Schmidt, D. N., Thierstein, H. R., Bollmann, J., and Schiebel, R.: Abiotic forcing of plankton evolution in the Cenozoic, Science, 303, 207-210, 2004b.

Schmidt, D. N., Lazarus, D., Young, J., and Kucera, M.: Biogeography and evolution of body-size of marine plankton, Earth-Sci. Rev., 78, 239-266, 2006.

Seki, O., Foster, G. L., Schmidt, D. N., Mackensen, A., Kawamura, K., and Pancost, R. D.: Alkenone and boron-based Pliocene $p \mathrm{CO}_{2}$ records, Earth Planet. Sc. Lett., 292, 201-211, 2010.

Shipboard Scientific Party: Site 607, in: Proceedings of the Ocean Drilling Program, Initial Reports, Leg 94, edited by: Ruddiman, W. F., Kidd, R. B., and Thomas, E., Ocean Drilling Program, College Station, 1987.

Shipboard Scientific Party: Site 999, in: Proceedings of the Ocean Drilling Program, Initial Reports, Leg 165, edited by: Sigurdsson, H., Leckie, R. M., and Acton, G. D., Ocean Drilling Program, College Station, 131-230, 1997.

Siegenthaler, U., Stocker, T. F., Monnin, E., Luthi, D., Schwander, J., Stauffer, B., Raynaud, D., Barnola, J.-M., Fischer, H., Masson-Delmotte, V., and Jouzel, J.: Stable carbon cycle-climate relationship during the late Pleistocene, Science, 310, 13131317,2005
Sigman, D. M., Jaccard, S. L., and Haug, G. H.: Polar ocean stratification in a cold climate, Nature, 428, 59-63, 2004.

Spero, H. J., Bijma, J., Lea, D. W., and Bemis, B. E.: Effect of seawater carbonate concentration on foraminiferal carbon and oxygen isotopes, Nature, 390, 497-500, 1997.

Solomon, S., Qin, D., Manning, M., Chen, Z., Marquis, M., Averyt, K. B., Tignor, M., and Miller, H. L. (Eds.): Climate Change 2007: The Physical Science Basis. Contribution of Working Group I to the Fourth Assessment Report of the Intergovernmental Panel on Climate Change, Cambridge University Press, Cambridge, United Kingdom and New York, NY, USA, 2007.

Steinke, S., Chiu, H.-Y., Yu, P.-S., Shen, C.-C., Löwemark, L., Mii, H.-S., and Chen, M.-T.: $\mathrm{Mg} / \mathrm{Ca}$ ratios of two Globigerinoides ruber (white) morphotypes: implications for reconstructing past tropical/subtropical surface water conditions, Geochem. Geophys. Geosy., 6, Q11005, doi:10.1029/2005GC000926, 2005.

Takahashi, T., Sutherland, S. C., Sweeney, C., Poisson, A., Metzl, N., Tilbrook, B., Bates, N., Wanninkhof, R., Feely, R. A., Sabine, C., Olafsson, J., and Nojiri, Y.: Global sea-air $\mathrm{CO}_{2}$ flux based on climatological surface ocean $p \mathrm{CO}_{2}$, and seasonal biological and temperature effects, Deep-Sea Res. Pt. II, 49, 16011622, 2002.

Takahashi, T., Sutherland, S. C., Wanninkhof, R., Sweeney, C., Feely, R. A., Chipman, D. W., Hales, B., Friederich, G., Chavez, F., Sabine, C., Watson, A., Bakker, D. C. E., Schuster, U., Metzl, N., Yoshikawa-Inoue, H., Ishii, M., Midorikawa, T., Nojiri, Y., Körtzinger, A., Steinhoff, T., Hoppema, M., Olafsson, J., Arnarson, T. S., Tilbrook, B., Johannessen, T., Olsen, A., Bellerby, R., Wong, C. S., Delille, B., Bates, N. R., and de Baar, H. J. W.: Climatological mean and decadal change in surface ocean $p \mathrm{CO}_{2}$, and net sea-air $\mathrm{CO}_{2}$ flux over the global oceans, Deep-Sea Res. Pt. II, 56, 554-577, 2009. doi:10.1016/j.dsr2.2008.12.009, 2009.

Thierstein, H. R. and Young, J. R.: Coccolithophores - from molecular processes to global impact, Springer, Heidelberg, 565 pp., 2004.

Turley, C., Eby, M., Ridgwell, A. J., Schmidt, D. N., Brownlee, C., Findlay, H. S., Fabry, V. J., Feely, R. A., Riebesell, U., and Gattuso, J.-P.: The Societal challenge of ocean acidification, Mar. Pollut. Bull., 60, 787-792, 2010.

Young, J. R.: Size variation of Neogene Reticulofenestra coccoliths from Indian Ocean DSDP cores, J. Micropalaeontol., 9, 71-86, 1990.

Young, J. R. and Westbroek, P.: Genotypic variation within the coccolithophorid species Emilianiahuxleyi, Mar. Micropaleontol., 18, 5-23, 1991.

Zondervan, I.: The effects of light, macronutrients, trace metals and $\mathrm{CO}_{2}$ on the production of calcium carbonate and organic carbon in coccolithophores - a review, Deep-Sea Res. Pt. II, 54, 521537, 2007. 